Masaru Masuyama, Junichi Funayama and Nobutatsu Yamaoka: Developments of Multi-Functional Ceramics (MFC).

MFC based on $\mathrm{SrTiO}_{3}$ or $(\mathrm{Sr}, \mathrm{Ca}) \mathrm{TiO}_{3}$ ceramics were developed as a noise and surge absorption element. They have both characteristics of varistor and capacitor. They showed the excellent electrical characteristics such as $\varepsilon$ s.app; $(6 \sim 40) \times 10^{4}, \alpha ; 10 \sim 20$, the current surge absorption capabilities; $3000 \mathrm{~A} / \mathrm{cm}^{2}$ and so on. The semiconductive ceramic grains and the grain boundaries of a $\mathrm{SrTiO}_{3}$ ceramic with a $\mathrm{BL}$ structure were much effective on these electrical characteristics. So, these electrical characteristics were obtained by controlling the $\mathrm{BL}$ structure of $(\mathrm{Sr}, \mathrm{Ca}) \mathrm{TiO}_{3}$ base ceramics. The grain sizes of $\mathrm{SrTiO}_{3}$ ceramics were controlled between $10 \mu \mathrm{m}$ and $150 \mu \mathrm{m}$.

In addition, The increase of the leakage currency through a MFC was unobserved after supplying several high surge impulses, while that of a $\mathrm{ZnO}$ ceramic varistor was much more in the same condition.

When MFG was applied on a power transformer circurt and a fast rise-up impulse noise were supplied to the cercuit, it has been comfirmed that the induced noise level observed on a secondary transformer circuit can be depressed to lower level. In consequent, MFC is available to prevent electrical equipments from being damaged by a noise or a high surge energy.

(Received July 8, 1987)

\section{MFC の開発背景}

マルチファンクショナルセラミックス (MFC) は，千 タン酸ストロンチウムを主成分とした半導体セラミック スであり，バリスタ機能とコンデンサ機能との両機能を 兼ね備えた素子である。

Table 1 は代表的なセラミックバリスタの開発背景を 示したすのである. 電子機器の能動素子が真空管からト ランジスタ,IC 等の半導体素子になったとき, 電子機器 のサージに対する耐力は著しく低下した，乙の時ギャッ プ式避雷器や $\mathrm{SiC}$ バリスタに変わってサージ吸収性に 優れた $\mathrm{ZnO}$ バリスタが開発され急速に普及した。その 後 IC から LSI とさらにその駆動電圧が低下するに従 ってサージのみならず各種ノイズによる電子機器の誤動 作が大きな問題となり，サージ対策と同時にノイズ対策 が必要となってきた。
チタン酸ストロンチウム系複合機能素子 (MFC) はと のような背景の中でノイズまです吸収するバリス夕とし て開発された新しいサージ，ノイズ対策部品として注目 されている.

チタン酸ストロンチウム系複合機能素子の特徽は, 従 来の他のバリスタとば異なり大きな静電容量をるったコ ンデンサ機能と優れたバリス夕機能とを兼极備えた素子 である。

\section{II 複合機能素子 $(\mathbf{M F G})$}

\section{П-1 材料とその基本特性}

Fig. 1 及び Fig. 2 は複合機能素子の作製工程を示した ものである. 出発材料は $\mathrm{SrTiO}_{3}$ または $\mathrm{Sr}$ の一部を $\mathrm{Ca}$ に置換した $(\mathrm{Sr}, \mathrm{Ca}) \mathrm{TiO}_{3}$ を主成分とし，とれに添加 剂を加えた材料からなる. 次にボールミルにて混合した 後, 有機バインダを加え造粒体を作り所定の寸法に成型

Table 1 The developing background of main ceramic varistors.

\begin{tabular}{|c|c|c|c|c|c|}
\hline & & $\mathrm{SiC}$ & $\mathrm{ZnO}$ & $\mathrm{SrTiO}_{3}$ & $(\mathrm{Sr}, \mathrm{Ca}) \mathrm{TiO}_{3}$ \\
\hline \multirow{3}{*}{$\begin{array}{l}\text { 時 } \\
\text { 帒 } \\
\text { 背 } \\
\text { 景 }\end{array}$} & 主な能動素子 & 真空管 & $\operatorname{Tr}, I C$ & \multicolumn{2}{|c|}{ IC, LSI（駆動電厌の低下） } \\
\hline & サージ対策の必要性 & $\triangle$ & $\mathrm{O}$ & \multicolumn{2}{|c|}{$\mathrm{O}$} \\
\hline & ノイズ対策の必要性 & $\triangle$ & $\triangle$ & \multicolumn{2}{|c|}{ (2) } \\
\hline \multirow{3}{*}{$\begin{array}{l}\text { 主 } \\
\text { な } \\
\text { 特 } \\
\text { 性 }\end{array}$} & 静 電 容 量 & 小 & 中 & 大 & 大 \\
\hline & 非 直 線 係 数 & $3 \sim 7$ & $20 \sim 70$ & $3 \sim 15$ & $3 \sim 20$ \\
\hline & サ - ジ 耐 量 & 大 & 大 & 大 $(1800 \mathrm{~A} / \mathrm{cr}$ & 大 $\left(3000 \mathrm{~A} / \mathrm{cm}^{2}\right)$ \\
\hline
\end{tabular}

*第 5 回（昭和61年度）技術進歩賞受賞, 1983年 9 月 Am. Ceram. Soc., Proc. the 5th Meeting on Ferroelectric Mat. and Their appl., Kyoto 1985, Jpn. J. Appl. Phys., 昭和62年 6 月本協会春季大会飞て発表, 昭和62年 7 月 3 日受理.

** 太陽誘電(株), $=370-33$ 群馬県群馬郡榛名町上里見 1660. 


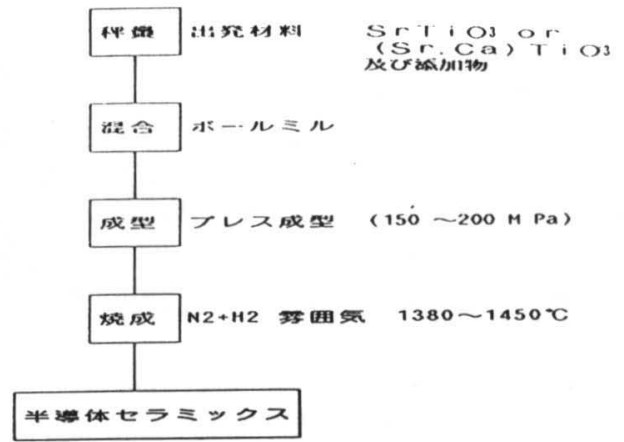

Fig. 1 The manufocturing procdss I of Multi-Functional Ceramics (MFC).

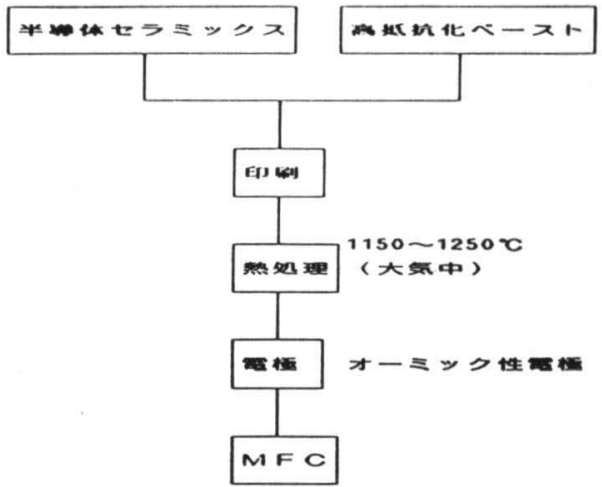

Fig. 2 The manufacturing process II of Multi-Functional Ceramic (MFC).

する. 次に $\mathrm{N}_{2}+\mathrm{H}_{2}$ からなる雲囲気中にて $1380 \sim 1450^{\circ} \mathrm{C}$ において焼成して半導体セラミックスを作製する. 次に 得られた半導体セラミックスに Fig. 2 に示すように高 抵抗化ペーストを塗布し，1150 1250 ${ }^{\circ} \mathrm{C}$ の大気中にて 熱処理を行いペースト成分を熱拡散させる，次にオーミ ック電極を印刷焼付けして複合機能素子 (MFC) を作製

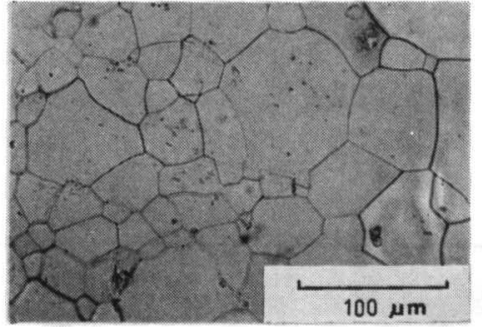

$1380^{\circ} \mathrm{C}$

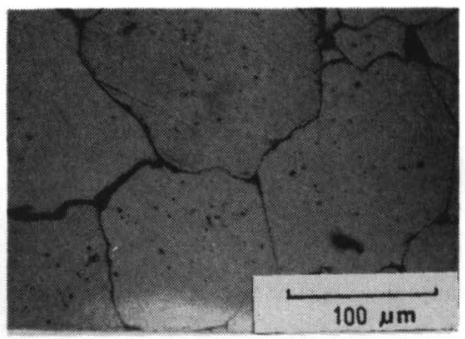

$1470^{\circ} \mathrm{C}$
する.

次にこのようにして得られた半導体セラミックス及び 複合機能素子の性質について紹介する.

Photo. 1 は Fig. 1 における焼成温度を変えたときの 半導体セラミックスの断面熱エッチング写真を示したあ のである. 焼成温度が $1380^{\circ} \mathrm{C}$ においては平均粒子径は $50 \mu \mathrm{m}$ であり粒子は Photo. 1 に示すように不均一な状 態である. $1430^{\circ} \mathrm{C}$ においては平均粒子径は $85 \mu \mathrm{m}$ であ り粒子は均一な状態となる， $1470^{\circ} \mathrm{C}$ においては平均粓 子径は $100 \mu \mathrm{m}$ でありこの状態においても粒子は均一で ある. このように焼成温度により結晶粒子の大きさと粒 子の均一性は決定される. この半導体セラミックスの結 晶粒子の大きさは, $\mathrm{SrTiO}_{3}$ 系 $\mathrm{MFC}$ の特性を決定する 上で重要なファクターとなっている.

次にこの半導体セラミックスの焼成温度に対する比抵 抗の変化を示したあのが Fig. 3 である. 図からわかるよ うに焼成温度が高くなるに連れて比抵抗は小さくなり， 例えば $1380^{\circ} \mathrm{C}$ において $0.2 \Omega \mathrm{cm}, 1430^{\circ} \mathrm{C}$ において $0.07 \Omega \mathrm{cm}, 1470^{\circ} \mathrm{C}$ において $0.06 \Omega \mathrm{cm}$ となった. この 半導体セラミックスの比抵抗は MFCのバリスタ機能に おける電圧非直線性とコンデンサ機能におけるインピー ダンス特性に重要なファクターとなっていることがわか っている.

次に MFC の性質について紹介する. Fig. 4 は $\mathrm{SrTiO}_{3}$ 系 $\mathrm{MFC}$ の粒子の大きさに対する見掛け誘電率 $\varepsilon \mathrm{s}$. APP, $\mathrm{V}_{1 \mathrm{~mA}}, \alpha$ との関係を示したあのである. 図からわかるよ うに結晶粒子径が大きくなるに連れて $\mathrm{V}_{1 \mathrm{~mA}}$ は小さくな り，また $\varepsilon_{\mathrm{S} . \mathrm{APP}}$ は大きくなる．また $\alpha$ は小さくなる，具 体的な特性值としては粒子径 $30 \mu \mathrm{m}$ で $\mathrm{V}_{1 \mathrm{~mA}}=50 \mathrm{~V} / \mathrm{mm}$, $\varepsilon_{\mathrm{S} . \mathrm{APP}}=10000, \alpha=15$ が得られ, 粒子径 $90 \mu \mathrm{m}$ では $\mathrm{V}_{\mathrm{l}}={ }_{\mathrm{mA}} 12 \mathrm{~V} / \mathrm{mm}, \varepsilon_{\mathrm{S} . \mathrm{APP}}=280000, \alpha=11$, 粒子径 $150 \mu \mathrm{m}$

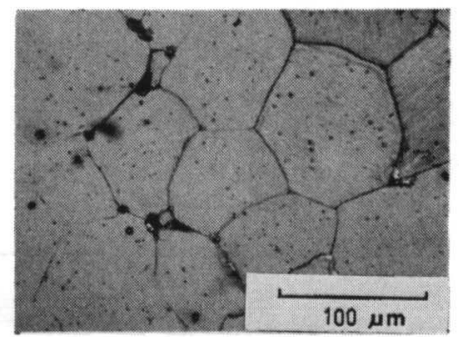

$1430^{\circ} \mathrm{C}$

Photo. 1 The micrographs of polished and thermally etched surfaces of semiconductive $\mathrm{SrTiO}_{3}$ ceramics fired at each temparature. 


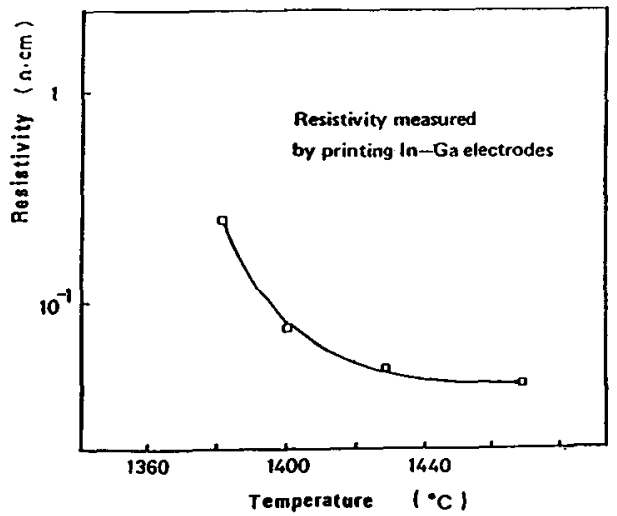

Fig. 3 The resistivity of semiconductive $\mathrm{Sr}^{\prime} \mathrm{TiO}_{3}$ samples.

では $\mathrm{V}_{1 \mathrm{~mA}}=7 \mathrm{~V} / \mathrm{mm}, \varepsilon_{\mathrm{s} . \mathrm{APP}}=380000, \alpha=10$ が得られ る. とのように MFC のバリスタ特性及び誘電特性は結 晶粒子径婂よって大きく変化する。

次に $\mathrm{SrTiO}_{3}$ の $\mathrm{Sr}$ の一部を $\mathrm{Ca}$ で置換した系の結晶 粒子径に対する $\varepsilon_{\mathrm{S} . \mathrm{APP}}, V_{1 \mathrm{~mA}}, \alpha$ の挙動を示したものが Fig. 5 である. Sr の一部を $\mathrm{Ca}$ で置換すると結晶粒子 は小さくなり，Ca の置换量が增えるに連れて結晶粒子 は小さくなる傾向にある. 結晶粒子に対しての $\alpha, \mathrm{V}_{1 \mathrm{~mA}}$, $\varepsilon_{\mathrm{S} . \mathrm{APP}}$ の挙動は Fig. 4 之同様な傾向である. 具体的には $\mathrm{Sr}_{0.85} \mathrm{Ca}_{0.15} \mathrm{TiO}_{3}$ では $7 \mu \mathrm{m}$ の結晶粒子径で $\varepsilon_{\mathrm{S} . \mathrm{APP}}=$ $10000, V_{1 \mathrm{~mA}}=400 \mathrm{~V} / \mathrm{mm}, \alpha=20$ が得られる. $\mathrm{Sr}_{0.95}$ $\mathrm{Ca}_{0.05} \mathrm{TiO}_{3}$ では $17 \mu \mathrm{m}$ 結晶粒子径で $\varepsilon \mathrm{s}$. APP $=25000$, $\mathrm{V}_{1 \mathrm{~mA}}=75 \mathrm{~V} / \mathrm{mm}, \alpha=15$ が得られる. $\mathrm{SrTiO}_{3} \mathrm{MFC}$ と 同様に ( $\mathrm{Sr}, \mathrm{Ca}) \mathrm{TiO}_{3} \mathrm{MFC}$ はその結晶粒子の大きさによ ってバリス夕特性と誘電特性をコントロールするととが 可能である. また $\mathrm{Sr}$ の一部を $\mathrm{Ca}$ で置換することによ り結晶粒子の大きさのコントロール範囲が広がり，さま

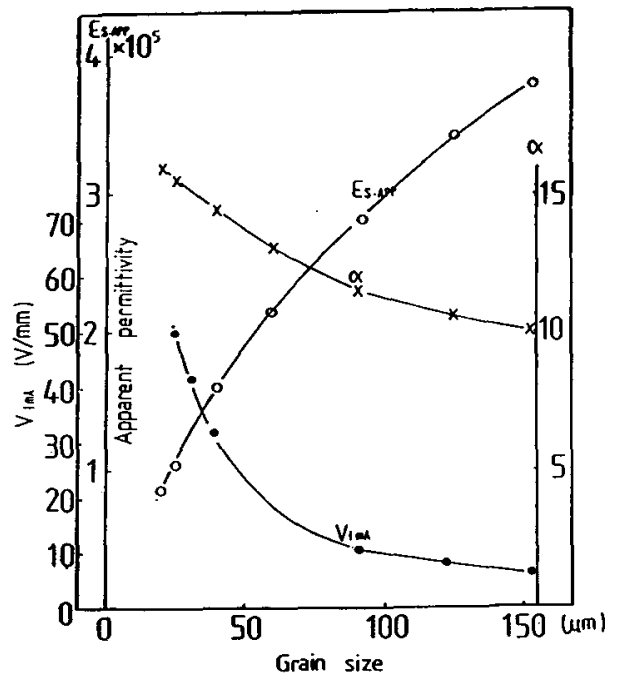

Fig. 4 The apparent permittivity, the $\mathrm{V}_{1 \mathrm{~mA}}$ and the $\alpha$ in relation to the grain size of $\mathrm{MFC}$ based on $\mathrm{SrTiO}_{3}$ ceramics.

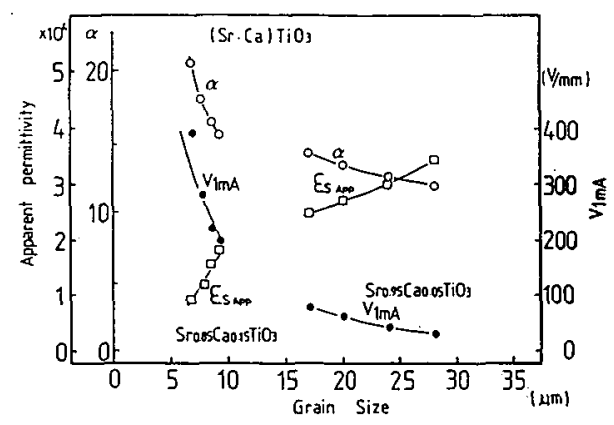

Fig. 5 The apparent permittivity, the $\mathrm{V}_{1 \mathrm{~mA}}$ and the $\alpha$ in relation to the grain size of $\mathrm{MFC}$ based on $(\mathrm{Sr}, \mathrm{Ca})$ $\mathrm{TiO}_{3}$ ceramics.

ざまな用途に合った材料特性の選抧が可能となる。

次に $(\mathrm{Sr}, \mathrm{Ca}) \mathrm{TiO}_{3}$ 複合機能素子のコンデンサとバリ スタとしての基本的性質について緑介する.

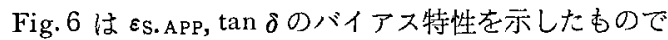
ある. 試料は $\mathrm{Sr}_{0.95} \mathrm{Ca}_{0.05} \mathrm{TiO}_{3}$ \& $\mathrm{Sr}_{0.85} \mathrm{Ca}_{0.15} \mathrm{TiO}_{3}$ の それぞれ代表的な試料を用いた。. $\mathrm{Sr}_{0.95} \mathrm{Ca}_{0.05} \mathrm{TiO}_{3}$ は電 圧が $12 \mathrm{~V} / \mathrm{mm}$ までは $\tan \delta$ はほとんど変化しないが $12 \mathrm{~V} / \mathrm{mm}$ を超えると急激に增加する．また $\mathrm{Sr}_{0.85} \mathrm{Ca}_{0.15}$ $\mathrm{TiO}_{3}$ では $100 \mathrm{~V} / \mathrm{mm}$ までは $\tan \delta$ はほとんど変化しな いが $100 \mathrm{~V} / \mathrm{mm}$ を超えると急激に增加する。一方 $\varepsilon$ S.APP は $\mathrm{Sr}_{0.95} \mathrm{Ca}_{0.05} \mathrm{TiO}_{3}$ では $12 \mathrm{~V} / \mathrm{mm}$ を超えても $\mathrm{Sr}_{0.85}$ $\mathrm{Ca}_{0.15} \mathrm{TiO}_{3}$ では $100 \mathrm{~V} / \mathrm{mm}$ を超えてもほとんど変化し ていない. Fig. 7 は Fig. 6 における試料のV-I 特性を 示したものである.いずれの試料の V-I 特性も非線形 となりバリスタ特性を示していることがわかる．Fig. 6 及び Fig.7 を具体的に見ると $\mathrm{Sr}_{0.85} \mathrm{Ca}_{0.15} \mathrm{TiO}_{3}$ では $10^{-7} \mathrm{~A}$ の電流点では $700 \mathrm{M} \Omega$ の絶縁抵抗と $\tan \delta$ が $1 \%$ のコンデンサとなっている，さらに電壬が增加して

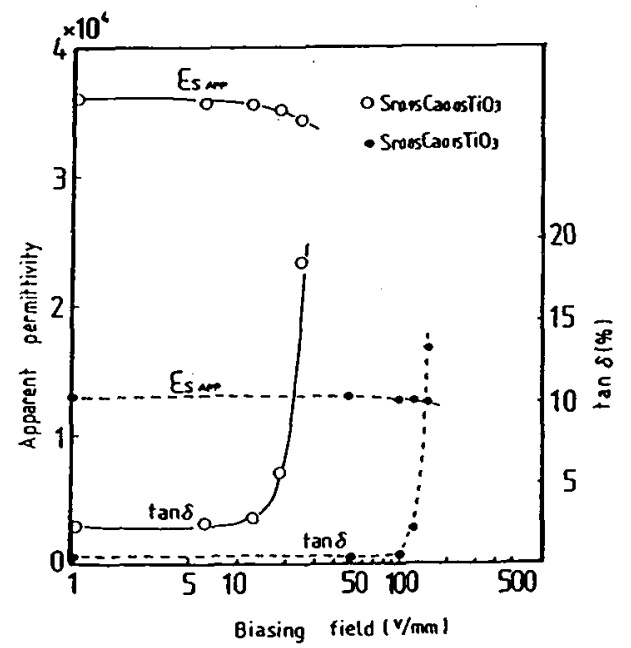

Fig. 6 The frequency dependence of the apparent permittivity and the dissipation factor of $\mathrm{MFC}$ based on (Sr, Ca) $\mathrm{TiO}_{3}$ ceramics. 


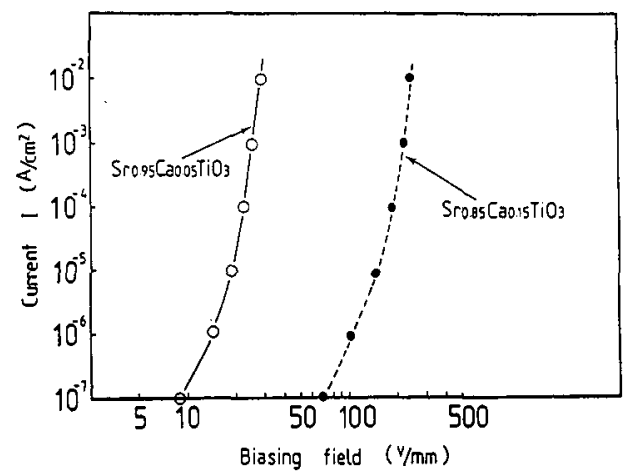

Fig. 7 The vo tage current characteristics of MFC based on $(\mathrm{Sr}, \mathrm{Ca}) \mathrm{TiO}_{3}$ ceramics.

$10^{-3} \mathrm{~A}$ の電流点では $\mathrm{V}_{1 \mathrm{~mA}}=200 \mathrm{~V} / \mathrm{mm}, \alpha=16$ のバリス 夕となっているととがわかる. また, $\mathrm{Sr}_{0.95} \mathrm{Ca}_{0.05} \mathrm{TiO}_{3}$ K おいて $10^{-7} \mathrm{~A}$ の電流点では $90 \mathrm{M} \Omega$ の絶縁抵抗之 $\tan \delta$ が $2 \%$ のコンデンサとなる.さらに電圧が増加して $10^{-3}$ $\mathrm{A}$ の電流点では $\mathrm{V}_{1 \mathrm{~mA}}=24 \mathrm{~V} / \mathrm{mm}, \alpha=13$ のバリスタと なる.また Fig. 6 亿おける $\tan \delta$ の急激な增加は Fig. 7 においていずれす $10^{-6} \mathrm{~A}$ 以上の急激な電流の增加領域 で生じているととがわかる。

Fig. 8 は $\varepsilon_{\mathrm{S} . \mathrm{APP}}, \mathrm{V}_{\mathrm{lmA}}$ の温度特性を示したむので, 試

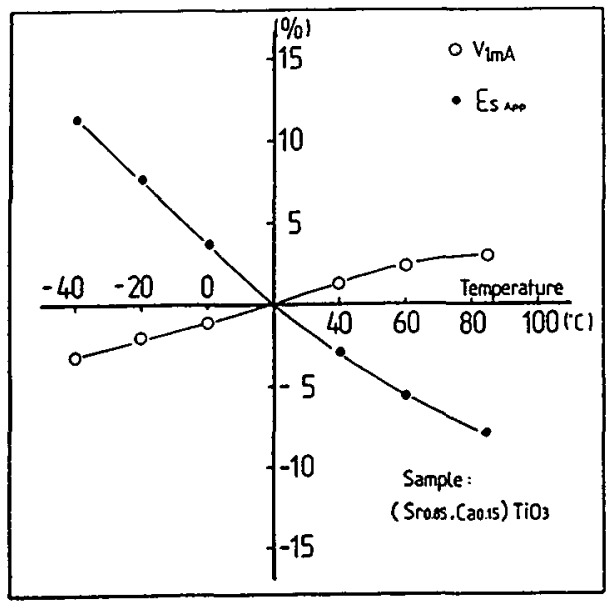

Fig. 8 The temperature dependence of the $\mathrm{V}_{1 \mathrm{~mA}}$ of $\mathrm{MFC}$ based on ( $\mathrm{Sr}, \mathrm{Ca}$ ) $\mathrm{TiO}_{3}$ ceramics.

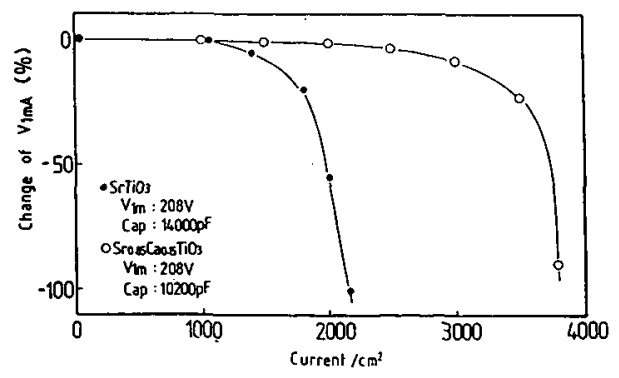

Fig. 9 The surge current resulting when high energy wave $(80 / 20 \mu \mathrm{sec})$ and supplied 2 times $/ 5 \mathrm{~min}$.
Table 2 Result.

\begin{tabular}{c|c|c}
\hline & $\mathrm{SrTiO}_{3}$ 采 & $(\mathrm{Sr}, \mathrm{Ca}) \mathrm{TiO}_{3}$ 系 \\
\hline 粒子径 $(\mu \mathrm{m})$ & $20 \sim 150$ & $5 \sim 40$ \\
\hline $\mathrm{V}_{1 \mathrm{~mA}}(\mathrm{v} / \mathrm{mm})$ & $7 \sim 100$ & $50 \sim 400$ \\
\hline$\alpha$ & $3 \sim 15$ & $3 \sim 20$ \\
\hline$\varepsilon(\times 104)$ & $6 \sim 40$ & $1 \sim 20$ \\
\hline $\begin{array}{r}* \text { \# 耐量 } \\
\left(\mathrm{A} / \mathrm{cm}^{2}\right)\end{array}$ & $\sim 1800$ & $\sim 3000$ \\
\hline
\end{tabular}

料は $\mathrm{Sr}_{0.85} \mathrm{Ca}_{0.15} \mathrm{TiO}_{3}$ を用いた. $\mathrm{V}_{1 \mathrm{~mA}}$ の温度変化は $-40 \sim 85^{\circ} \mathrm{C}$ において 5 \%以内にあり高温側にて $\Delta \mathrm{V}_{1 \mathrm{~mA}}$ がプラスであるととから高温使用における信頼性の高い あのとなっている.一方 $\varepsilon_{\mathrm{S} . \mathrm{APP}}$ の温度変化は一 $-40 \sim 85^{\circ} \mathrm{C}$ に括いて $\pm 13 \%$ 以内にあり通常のコンデンサと比較して あ良好なレベルにある。

Fig. 9 は $\mathrm{SrTiO}_{3} \mathrm{MFC}$ と $(\mathrm{Sr}, \mathrm{Ca}) \mathrm{TiO}_{3}$ 系 $\mathrm{MFC}$ と のサージ電流印加特性を示したすのである，それぞれの 試料は $\mathrm{V}_{\mathrm{ImA}}$ を合わせてある. 図からわかるように $\mathrm{Sr}$ $\mathrm{TiO}_{3} \mathrm{MFC}$ では $1000 \mathrm{~A} / \mathrm{cm}^{2}$ 以下のサージ 電流印加に 対して $\Delta \mathrm{V}_{1 \mathrm{~mA}}$ は，ほとんど変化しない，しかし 1800 $\mathrm{A} / \mathrm{cm}^{2}$ を超えると急激任変化する. 一方 $\mathrm{Sr}_{0.85} \mathrm{Ca}_{0.15}$ $\mathrm{TiO}_{3} \mathrm{MFC}$ では $2500 \mathrm{~A} / \mathrm{cm}^{2}$ 以下では $\Delta \mathrm{V}_{1 \mathrm{~mA}}$ はほとん ど変化しない．しかし $3500 \mathrm{~A} / \mathrm{cm}^{2}$ を超えると急激に变 化する. このように Sr の一部を $\mathrm{Ca}$ で置換することに よりサージ耐量の大きなバリスタを得るととが可能とな る.

以上の結果をまとめると Table 2 のようになり $\mathrm{SrTi}$ $\mathrm{O}_{3}$ 及び $\mathrm{Sr}$ の一部を $\mathrm{Ca}$ で置換した $(\mathrm{Sr}, \mathrm{Ca}) \mathrm{TiO}_{3} \mathrm{MFC}$ とむどあコンデンサ機能とバリス夕機能の画機能を兼和 備えた複合機能素子であることがわかる.

\section{ПI-2 複合機能と MFC の特徽}

$\mathrm{MFC}$ はコンデンサ機能とバリスタ機能とを兼敉備え た複合機能素子であることは，てれまでに紹介してきた。 そこで MFCの複合機能としての特長について以下紹介 する。

MFC の機能は Fig. 10 に示す 4 つの機能に代表され る.コンデンサ機能としての高周波ノイズ吸収機能，バ リスタ機能としてのサージ吸収機能, コンデンサ機能と バリスタ機能亡が複合された立上がりの早いパルス吸収 機能それに MFC 独自の自己復帰機能がある.こてに

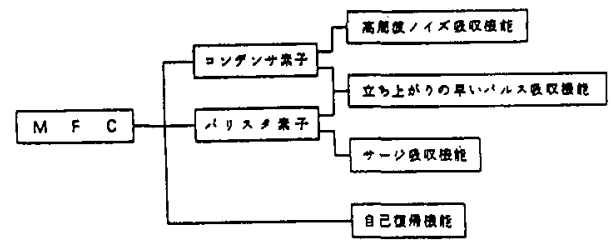

Fig. 10 The 4 functions of "MFC". 


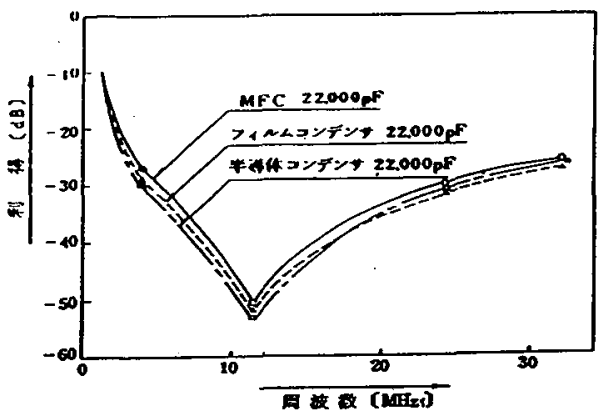

Fig. 11 The comparison of frequency characteristics of MFC and capacitors having same capacitance value.

4 つの機能についての事例を紹介する。

(a)コンデンサ機能

Fig. 11 は MFC と同じ静電容量をすつフィルムコン デンサ及び半導体コンデンサの $50 \Omega$ 系での周波数に刘 する減衰特性の比較例である，MFC は従来の優れたコ ンデンサと同等なレベルの特性をむっていることがわか る.

(b)バリスタ機能

Fig. 12 は MFC のサージ吸収機能を示したものであ り試料には雷サージ試験に通常使用されている $1.2 / 50$ $\mu \mathrm{sec}$ の電生サージ波形で波高值 $12 \mathrm{kV}$ の電生サージを 印加した．この結果，図に示されるような制限電王波形 となり，その波高值は $750 \mathrm{~V}$ であった。このようにサー ジに対して MFC は従来のバリスタの吸収性に近い特性 をあっている。

(c)コンデンサ機能十バリスタ機能

Fig. 13 は立上がりがナノセックオーダのパルス性ノ

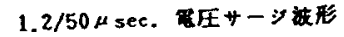

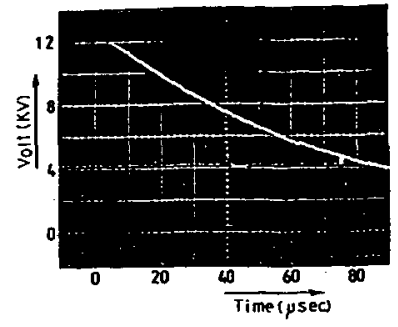

SrTiOっ系ハyスタによる 胡展電压波形时

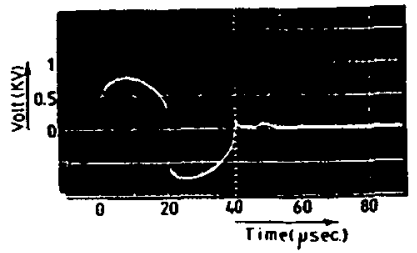

Fig. 12 The surge absorption characteristics of MFC based on $\mathrm{SrTiO}_{3}$ ceramics.

イズに対ずるコンデンサ, $\mathrm{ZnO}$ バリスタ, MFC の応答 性を比較した例である。試料特性はコンデンサは $\mathrm{MFC}$ と同容量， $\mathrm{ZnO}$ バリスタは $\mathrm{V}_{1 \mathrm{~mA}}$ が同じものを使用し た。標隼波形としては，図に示されているような 1000V の波高值の短形波を用いた．との結果, コンデンサは立 上がりの $\mathrm{dV} / \mathrm{dt}$ を小さくするがピーク電压を押えられ ない，ZnOバリスタではバリスタ特性により電王を低く 制限できるが, 立上がり部分の応答遅れがみられる。一 方, MFC は立上がりは $\mathrm{dV} / \mathrm{dt}$ をコンデンサ機能で低く 押え，ピーク電圧をバリスタ機能で低く押えることがわ かる.とのように MFC は立上がりの早いパルス性ノイ
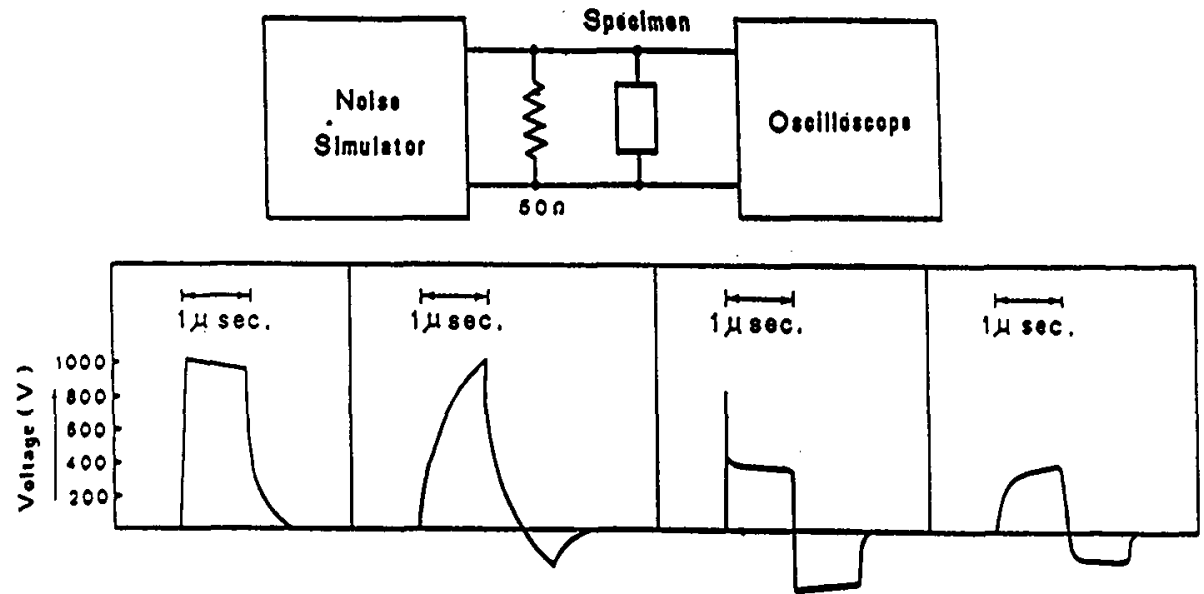

探漕波形
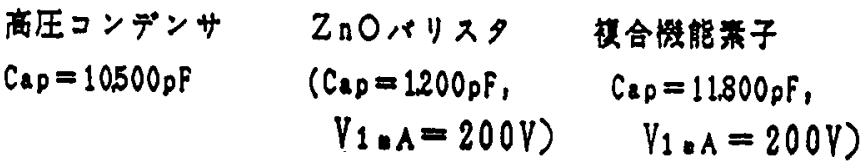

Fig. 13 The comparison of absorption effect of a MFC, a capacitor and a Zinc Oxide varistor against fast rise-up pulse. 


\begin{tabular}{|c|c|c|}
\hline & $\left(\mathrm{Sr} . \mathrm{Ca}_{\mathrm{a}}\right) \mathrm{TiO}$ & $2 \mathrm{n} 0$ ・リス \\
\hline パリスタ西在 & $208 \mathrm{~V}$ & $208 \mathrm{BV}$ \\
\hline 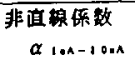 & 17 & 5 \\
\hline 解容 & $12.300 \mathrm{pF}$ & $1.010 \mathrm{pF}$ \\
\hline $\tan \delta$ & $0.53 \%$ & $2.1 \%$ \\
\hline
\end{tabular}

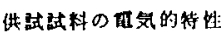

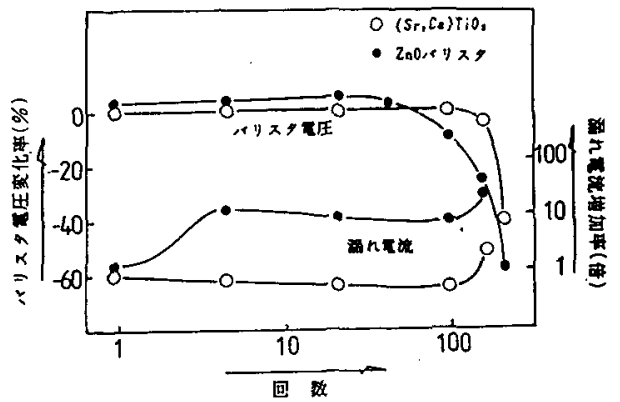

Fig. 14 The variation rate of varistor voltage and leakage current when a $1800 \mathrm{~A} / \mathrm{cm}^{2}$ surge current is applied to a $M F C$.

ズに対して霓れた吸収性をすっているととがわかる。

(d)自己復㷌機能

$\mathrm{MFC}$ の自己復㷌機能は, $\mathrm{SrTiO}_{3}$ 系バリスタがあつ 独特の性質でサージ吸収後に初期の絶縁抵抗つまり電在 一電流特性に完全愎㷌する機能である。この結 果, MFC に多数回サージを印加したとき漏れ電流の增大に よる発熱, 発熱による漏れ電流の増大というループに入 って焼損に至る可能性がきわめて少なく高い信頼性を確 保することができる。

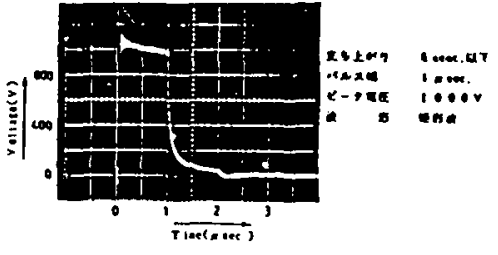

バルス性ノイズ波形

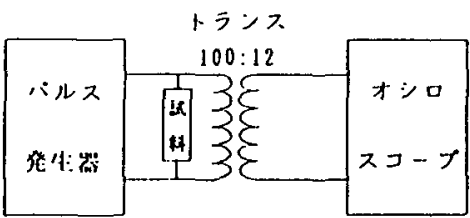

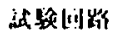

\begin{tabular}{|c|c|c|c|}
\hline & (Sr.Ca)TiO & 2n0パリスタ & コンデンサ \\
\hline 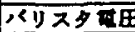 & $205 \mathrm{~V}$ & $205 \mathrm{~V}$ & 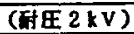 \\
\hline 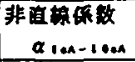 & 17.6 & 58 & - \\
\hline 西它 & $10.920 \mathrm{pP}$ & $1,130 \mathrm{pP}$ & $10.200 \mathrm{pF}$ \\
\hline $\tan \delta$ & $0.48 \%$ & $2.2 \%$ & $0.17 \%$ \\
\hline
\end{tabular}

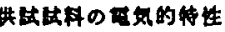

Fig. 16 The test circuit and the electrical characteristics of specimens offered.

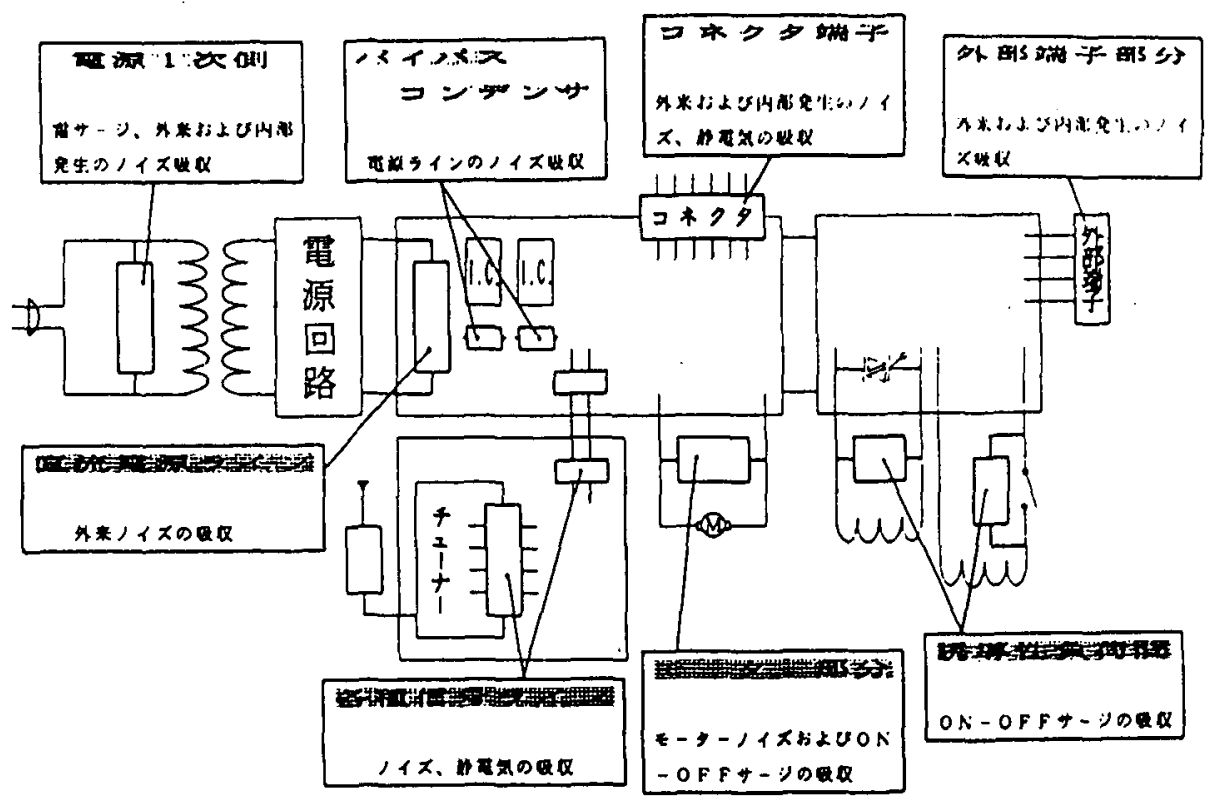

Fig. 15 The typical applications of $\mathrm{MFC}$ based on $\mathrm{SrTiO}_{3}$ ceramics. 
Fig. 14 は $8 / 20 \mu \mathrm{sec}$ の標準サージ電流波形で 1800 $\mathrm{A} / \mathrm{cm}^{2}$ のサージ電流を 1 分間隔にて多数回印加したと きの印加回数に対するバリス夕電圧上漏れ電流の変化例 を示す. 試験試料は，( $\mathrm{Sr}, \mathrm{Ca}) \mathrm{TiO}_{3}$ 系 $\mathrm{MFC}, \mathrm{ZnO}$ バリ スタとも同じバリスタ電生を使用した。

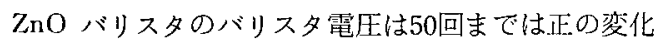
を示し，その後，緩やか纪低下し192回でショート状態と なったまな漏れ電流は初期段階で15倍まで急激に增加 して，その後ほぼ安定するが100回を超えると再び増加 した. ( $\mathrm{Sr}, \mathrm{Ca}) \mathrm{TiO}_{3}$ 系 $\mathrm{MFC}$ は140回までバリスタ䉓压, 漏れ電流共にほ上んど変化せず, その後バリス夕電生の 低下と漏れ電流の增大が緩や汃に進み，最終的に202回 でショート状態となった．多数回サージを連続印加した 上き，乙のように $\mathrm{ZnO}$ バリスタは初期的に漏れ電流か 増大するのに対して $(\mathrm{Sr}, \mathrm{Ca}) \mathrm{TiO}_{3}$ 系 $\mathrm{MFC}_{\text {は }}$ 破烄に至

\section{るまで安定である。}

$$
\text { III 応用 }
$$

Fig. 15 は MFC の代表的な用途を示したあのである. 用途上しては電源一次側, バイパスコンデンサ,コネク 夕端子, 外部端子部分, 各種信号ライン，モーター部分 誘導性負荷等の用途がある，この中で電源一次㒋に使用 したときの笑験例を示す。

Fig. 16 は試験回路及び供試試料の電気的特性を示し

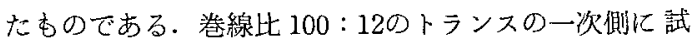
料を接続し，Fig. 16 に示された波形のパルス性/イズ を印加してトランスの二次側に誘起される電圧波形を観 测した. Fig.17 はその結果を示したあのである.

吸収孳子を接続しない之き二次側には，印加パルス性 ノイズの立上がりに起因するピーク電压 $342 \mathrm{~V}$ が観测さ れた. $\mathrm{ZnO}$ バリスタを接続したときには，一次倒におけ
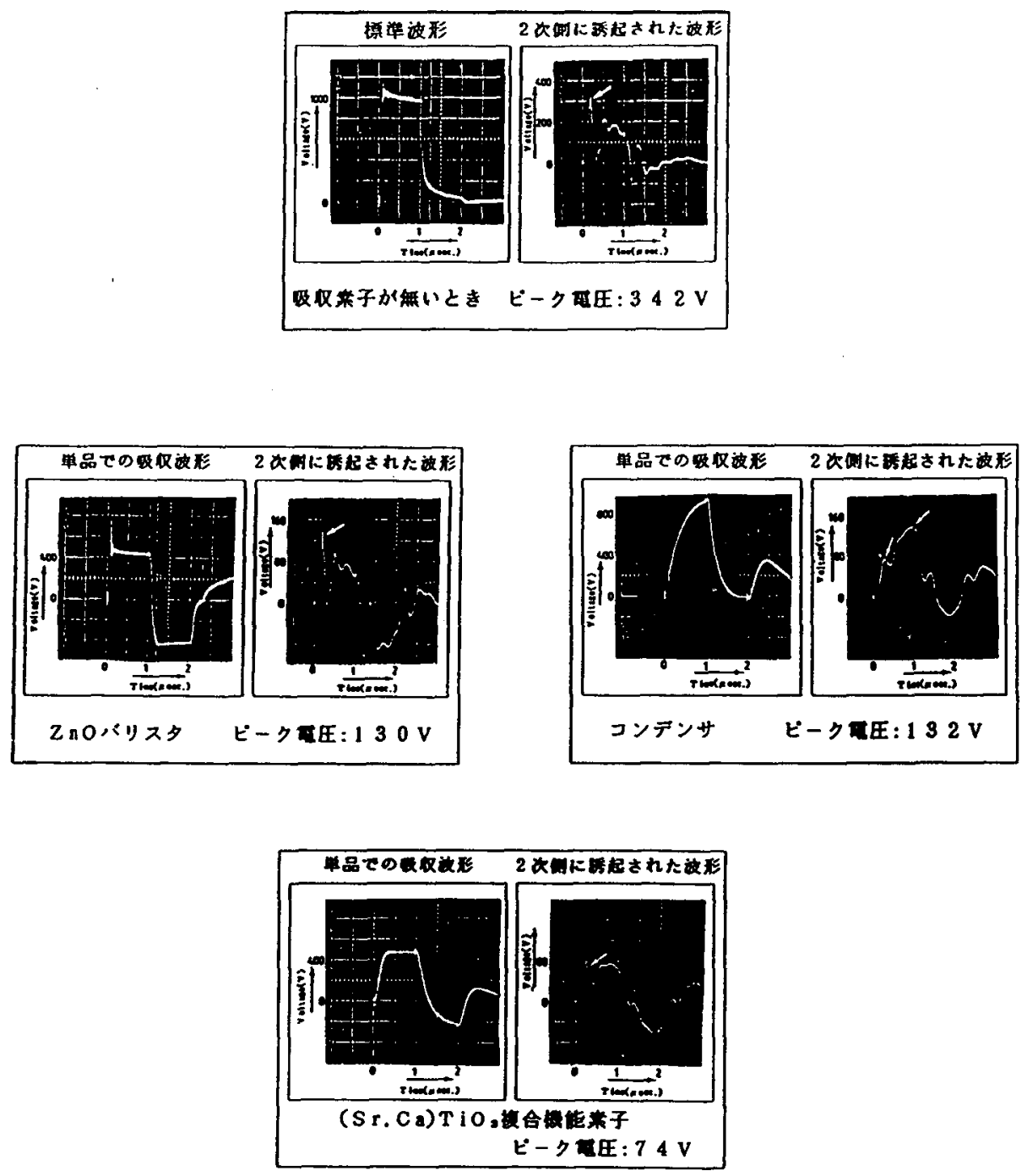

Fig. 17 The comparison of voltage wave observed on a primary transforme ciruit and a secondary transformer cincuit when a fast rise-up impulse noise were supplied to a power. 
る印加パルス性ノイズの立上がり部分の応答遅れがある ため，二次側にはこの部分に起因するピーク電圧 $130 \mathrm{~V}$ が観測された。コンデンサを接続したときには，一次側 での立上がりの dV/dt 抑制効果により，二次側でてれ に誘起されるピークは低くなるが，一次側での電圧を制 限できないため，乙れに誘起されるピーク電压 $132 \mathrm{~V}$ が 観測された。一方, $(\mathrm{Sr}, \mathrm{Ca}) \mathrm{TiO}_{3}$ 複合機能素子は一次側 での立上がり部分の $\mathrm{dV} / \mathrm{dt}$ を低隇し，かつ電王を制限 すると之から二次側唀起する電代を $74 \mathrm{~V}$ と低く押え ることができた，ての結果から MFC は立上がりが早く 高いピーク電告をあつパルス性ノイズに対してきわめて 良好な吸収性を示し，特に本実験のように電源一次側に 用いたとき，このようなノイズに誘起するノイズ䉓圧を
低く押えるととがわかる。

以上のように複合機能素子 (MFC) は 4 つの機能をも つ新しいタイプの半導体セラミックスで，その用途は非 常に広いものとなっている．今後ますます需要が増大す るノイズ刘策部品の中でさらに大きく発展することと考 えている。

\section{文献}

1) N. Yamaoka, M. Masuyama and M. Fukui: Am. Ceram. Soc. Bull., 62 [6] (1983).

2) D. Kaino, J. Funayama and N. Yamaoka: Jpn. J. Appl. Phys., 24 Suppl. [24-3] (1985), 120.

3）船山，増山，戒能，山岡：昭和61年電子通信学会総合全国 大会, 1-117. 